\title{
UJI AKTIVITAS ANTIBAKTERI EKSTRAK ETANOL DAUN AFRIKA (Vernonia amygdalina Del.) TERHADAP BAKTERI Escherichia coli ATCC 25922 SECARA In Vitro
}

\author{
Iklila Zahra', Susanti Erikania ${ }^{2}$, Oktaviarika Dewi $\mathbf{H}^{3}$ \\ 1,2,3) STIKES Bhakti Husada Mulia \\ e-mail: 1) iklilazhr21@gmail.com
}

\begin{abstract}
ABSTRAK
Obat tradisional merupakan bahan atau ramuan berupa tumbuhan, bahan hewan atau bahan lainnya. Salah satu contoh obat tradisional adalah Tanaman Daun Afrika (Vernonia amygdalina Del.). Daun Afrika (Vernonia amygdalina Del.) memiliki beberapa kandungan kimia seperti Flavanoid, alkaloid, tanin dan kandungan kimia lainnya yang diyakini berkhasiat untuk pengobatan beberapa penyakit seperti diabetes, hipertensi, asam urat dan antibakteri. Tujuan: Penelitian ini bertujuan untuk mengetahui potensi antibakteri pada Escherichia coli dengan menggunakan metode difusi cakram. Hasil Penelitian : Zona hambat antibakteri pada ekstrak etanol Daun Afrika (Vernonia amygdalina Del.) didapatkan hasil yaitu pada konsentrasi $20 \%$ sebesar $7,48 \pm 017 \mathrm{~mm} ; 40 \%$ sebesar $11,67 \pm 0,13 \mathrm{~mm}$; $60 \%$ sebesar $14,18 \pm 0,21 \mathrm{~mm}$ dan $80 \%$ sebesar $16,60 \pm 0,17 \mathrm{~mm}$. Daya hambat terbesar didapatkan pada konsentrasi ekstrak $80 \%$ yaitu sebesar 16,60 $\pm 0,17 \mathrm{~mm}$.
\end{abstract}

Kata kunci: Ekstrak Daun Afrika, Antibakteri, Difusi, Escherichia coli

\begin{abstract}
Traditional medicine is an ingredient or herb in the form of plants, animal ingredients or other ingredients. One example of traditional medicine is the African Leaf Plant (Vernonia amygdalina Del.). African leaves (Vernonia amygdalina Del.) have several chemical contents such as flavonoids, alkaloids, tannins and other chemical contents that are believed to be efficacious for the treatment of several diseases such as diabetes, hypertension, gout and antibacterial. Purpose: This study aims to as well as to determine the antibacterial potential of Escherichia coli by using the disc diffusion method. Result: The results of the antibacterial inhibition on ethanol extracts of African Leaves (Vernonia amygdalina Del.) are at a concentration of $20 \%$ of $7.48 \pm 017 \mathrm{~mm} ; 40 \%$ of $11.67 \pm 0.13$ $\mathrm{mm} ; 60 \%$ of $14.18 \pm 0.21 \mathrm{~mm}$ and $80 \%$ of $16.60 \pm 0.17 \mathrm{~mm}$. The greatest inhibitory power was obtained at $80 \%$ extract concentration which was $16.60 \pm 0.17 \mathrm{~mm}$.
\end{abstract}

Keywords: African Leaf Extract, Antibacterial, Difusion, Escherichia coli

\section{PENDAHULUAN}

Indonesia memiliki keanekaragaman hayati tertinggi kedua di dunia setelah Brazil dengan kekayaan flora lebih dari 56.000 spesies tumbuhan, hampir 
MEDFARM: Jurnal Farmasi dan Kesehatan, Vol.10, No.1, 2021, Hal. 28-34

e-ISSN : 2715-9957

p-ISSN: 2354-8487

19\% dari flora didunia. Flora di Indonesia banyak yang dapat dimanfaatkan untuk kehidupan sehari-hari, salah satunya dimanfaatkan untuk obat tradisional (Ferry, 2015). Obat tradisional adalah bahan atau ramuan bahan berupa bahan tumbuhan, bahan hewan, bahan mineral, sediaan cairan atau campuran dari bahan tersebut, yang secara turun temurun telah digunakan untuk pengobatan berdasarkan pengalaman (BPOM RI, 2005). Salah satu obat tradisional yang biasa digunakan adalah Daun Afrika (Vernonia amygdalina Del.). Daun tersebut digunakan sebagai obat sakit perut oleh masyarakat di sekitar daerah tempat tinggal peneliti. Penggunaan Daun Afrika (Vernonia amygdalina Del.) sebagai obat sakit perut telah lama digunakan secara turun temurun. Daun Afrika (Vernonia amygdalina Del.) merupakan salah satu jenis tumbuhan yang ada di Indonesia. Beberapa kandungan Daun Afrika (Vernonia amygdalina Del.) saponin, terpenoid, flavonoid, asam fenolat, terpen, dan tanin (Ijeh, 2010). Daun afrika (Vernonia amygdalina Del.) juga dikenal dengan nama daun seribu penyakit diyakini berhasiat untuk pengobatan diabetes, hipertensi, mengurangi kolesterol, asam urat, pembuangan racun dalam tubuh (detoksifikasi), rematik, usah tidur, kesemutan, demam, sakit kepala, infeksi tenggorokan, menghilangkan dahak, melancarkan buang air seni, menguatkan fungsi lambung, batuk dan gangguan pencernaan. (Dedy Muzaki, 2015). Manfaat lain dari Daun Afrika (Vernonia amygdalina Del.) adalah sebagai antibakteri.

Antibakteri adalah zat yang dapat membunuh atau menekan pertumbuhan atau reproduksi bakteri (Madigan, 2005). Senyawa kimia yang terkandung dalam Daun Afrika (Vernonia amygdalina Del.) terdapat antibakteri berupa flavonoid, saponin, tannin, alkaloid, steroid dan triterpenoid. Senyawa kimia tersebut memiliki aktivitas sebagai antibakteri dengan mekanisme yang berbeda. peneliti melakukan penelitian aktivitas antibakteri dari ekstrak etanol Daun Afrika (Vernonia amygdalina Del.) pada bakteri Escherichia coli karena bakteri ini merupakan bakteri yang sering berhubungan dengan manusia. Bakteri ini merupakan bakteri bagian dari mikroflora yang secara normal ada dalam saluran pencernaan manusia (Kusuma, 2010). Bakteri Escherichia coli menjadi patogen jika jumlah bakteri ini dalam saluran pencernaan meningkat atau berada di luar usus. Beberapa macam penyakit yang disebabkan oleh bakteri Escherichia coli antara lain adalah infeksi saluran kemih, infeksi 
MEDFARM: Jurnal Farmasi dan Kesehatan, Vol.10, No.1, 2021, Hal. 28-34

e-ISSN : 2715-9957

p-ISSN: 2354-8487

meningitis, diare, kejang perut, demam, gangguan pada ginjal dan infeksi intestine (Radji, 2010).

Berdasarkan uraian di atas, peneliti akan meneliti tentang aktivitas antibakteri ektrak etanol Daun Afrika (Vernonia amygdalina Del.) terhadap bakteri Escherichia coli secara In Vitro

\section{METODOLOGI PENELITIAN}

Penelitian ini merupakan penelitian eksperimental laboratorium dengan melakukan percobaan aktivitas antibakteri daun Afrika (Vernonia amygdalina Del.) terhadap bakteri Escherichia coli.

\section{Alat}

Cawan petri (Normax), erlenmeyer (Pyrex), pipet volume (Pyrex), batang pengaduk (Lokal), tabung reaksi (Pyrex), Lampu Spirtus (Lokal), Rak tabung (Lokal), Inkas (local), Incubator (Memert), Autoclave (SG41 46 280A), Oven besar (Binder), Oven kecil (Binder), Timbangan (SCA 301), Obyek glass (Slides), Beaker Glass (Pyrex, Duran), Mikroskop (13A), Gelas Ukur (Pyrex), Labu destilasi (Pyrex)

\section{Bahan}

Bahan yang digunakan pada penelitian ini meliputi : Media Nutrient Agar (NA), Pelarut DMSO, Antibiotik Kloramfenikol Aquadest steril, Etanol, Gram A (kristal violet), B (KI dan I2), C (Aseton dan etil Alkohol 90\%) dan D (Safranin), Formalin, Sampel Ekstrak Etanol Daun Afrika (Vernonia amygdalina Del.)

\section{Pembuatan Ekstrak}

Menggunakan metode maserasi sampai didapatkan ekstrak kental, dengan $10 \mathrm{~L}$ pelarut etanol 96\% untuk $1 \mathrm{~kg}$ serbuk Daun Afrika (Vernonia amygdalina Del.).

\section{Peremajaan Bakteri}

Satu ose dari biakan murni diambil, kemudian dimasukkan kedalam $10 \mathrm{ml}$ pepton $1 \%$ pada tabung reaksi dan dihomogenkan dengan vortex mixer, $1 \mathrm{ml}$ suspensi bakteri uji yang diambil dari tabung pertama, dimasukkan kedalam tabung kedua yang berisi $9 \mathrm{ml}$ pepton 1\%, dilakukan hingga tabung kelima atau hingga pengenceran 10-5, lalu Sebanyak $500 \mu$ l suspense bakteri diteteskan ke dalam cawan petri berisi media NB dan diratakan menggunakan batang L steril (Sutton, 2011). 
MEDFARM: Jurnal Farmasi dan Kesehatan, Vol.10, No.1, 2021, Hal. 28-34

e-ISSN : 2715-9957

p-ISSN: 2354-8487

\section{Uji Aktivitas Antibakteri}

Cakram disc kosong direndam dalam larutan uji pada seri konsentrasi ekstrak etanol Daun Afrika (Vernonia amygdalina Del.) konsentrasi 20\%, 40\%, 60\%, 80\% selama 30 menit. bakteri dengan pengenceran 10-5 dipipet $100 \mu \mathrm{l}$ kemudian dituang didalam cawan porselen, diratakan dengan arah berlawanan jarum jam. Cakram disc yang telah direndam dalam larutan uji diambil menggunakan pinset steril, kemudian diletakkan pada media yang telah berisi bakteri uji dengan cara ditekan lembut supaya menempel sempurna, Inkubasi pada suhu $37^{\circ} \mathrm{C}$ selama 24 jam. Kontrol negatif (DMSO 10\%) dan Kontrol positif (Kloramfenikol) 30 $\mu$ g/disc.

\section{HASIL DAN PEMBAHASAN}

Hasil ekstraksi diperoleh ekstrak kental sebanyak 124,9 gram. Dengan randemen sebesar 12,49\%. Berdasarkan penelitian yang dilakukan di Laboratorium Mikrobiologi Kampus Akafarma Sunan Giri Ponorogo, diperoleh hasil uji perbandingan aktivitas antibakteri ekstrak Daun Afrika (Vernonia amygdalina Del.) dengan kloramfenikol 30 $\mathrm{g} /$ disc sebagai kontrol positif dan DMSO 10\% sebagai kontrol negatif terhadap pertumbuhan bakteri Escherichia coli. Hasil diperoleh dari pengukuran zona hambat ekstrak Daun Afrika (Vernonia amygdalina Del.), dimana zona yang diukur adalah daerah yang tampak jernih yang tidak ditumbuhi oleh bakteri Escherichia coli. Konsentrasi yang digunakan yaitu persen (\%). Adapun hasil pengukuran zona hambat bakteri terdapat pada tabel dibawah ini

Tabel 1. Data Hasil Pengukuran Zona Hambat Ekstrak Daun Afrika (Vernonia amygdalina Del.) Terhadap Pertumbuhan Bakteri Escherichia coli

\begin{tabular}{|c|c|c|c|c|c|c|c|c|}
\hline \multirow[t]{2}{*}{ No. } & \multirow[t]{2}{*}{ Perlakuan } & \multirow[t]{2}{*}{$\mathrm{mg} / \mathrm{ml}$} & \multicolumn{4}{|c|}{$\begin{array}{c}\text { Zona Hambat Ekstrak Daun } \\
\text { Afrika (mm) }\end{array}$} & \multirow[t]{2}{*}{ Rata-rata \pm SD } & \multirow{2}{*}{$\begin{array}{l}\text { Resspon } \\
\text { Hambatan }\end{array}$} \\
\hline & & & $\mathrm{I}$ & II & III & IV & & \\
\hline 1. & Kontrol + & 0,03 & 27,1 & 26,9 & 27.3 & 26,8 & $27,1 \pm 0,16$ & Sangat Kuat \\
\hline 2. & Kontrol - & - & 0 & 0 & 0 & 0 & 0 & Tidak ada \\
\hline 3. & $20 \%$ & 200 & 7,3 & 7,4 & 7,7 & 7,5 & $7,48 \pm 0,17$ & Lemah \\
\hline 4. & $40 \%$ & 400 & 11,5 & 11,7 & 11,7 & 11,8 & $11,67 \pm 0,13$ & Sedang \\
\hline 5. & $60 \%$ & 600 & 14,2 & 13,9 & 14,4 & 14,2 & $14,18 \pm 0,21$ & Sedang \\
\hline 6. & $80 \%$ & 800 & 16,8 & 16,7 & 16,9 & 17,1 & $16,60 \pm 0,17$ & Kuat \\
\hline
\end{tabular}

Keterangan :

Kontrol $+=$ kelompok yang diberi perlakuan Kloramfenikol 30 $\mu \mathrm{g} /$ disc

Kontrol - = kelompok yang diberi perlakuan DMSO 10\% 
MEDFARM: Jurnal Farmasi dan Kesehatan, Vol.10, No.1, 2021, Hal. 28-34

e-ISSN : 2715-9957

p-ISSN: 2354-8487

Uji aktivitas antibakteri pada ekstrak Daun Afrika (Vernonia amygdalina Del.) terhadap pertumbuhan bakteri Escherichia coli menggunakan difusi agar dengan kertas cakram. Pada penelitian ini, peneliti menggunakan pembanding kontrol positif berupa paper disk yang sudah berisi kloramfenikol 30 $\mu \mathrm{g} /$ disk. Kontrol positif digunakan untuk melihat perbandingan diameter pada zona hambat bakteri dan untuk kontrol negatif yang digunakan adalah larutan DMSO $10 \%$ yang tidak memiliki daya hambat terhadap bakteri. Kontrol positif kloramfenikol digunakan karena kloramfenikol merupakan antibiotik berspektrum luas yang aktif terhadap bakteri gram positif dan gram negatif. Kloramfenikol bekerja dengan menghambat sintesis protein bakteri (Pratiwi, 2019). Pada penelitian yang telah dilakukan sebelumnya oleh Suryati (2017) menunjukkan bahwa kloremfenikol mampu menghambat bakteri Escherichia coli dengan sangat kuat. Sedangkan kontrol negatif menggunakan DMSO 10\%. Karena DMSO merupakan pelarut yang dapat melarutkan senyawa polar maupun nonpolar. Selain itu DMSO tidak memberikan daya hambat pertumbuhan bakteri, sehingga tidak mengganggu hasil dari pengujian aktivitas antibakteri (Utami, 2011).

Pengujian selanjutnya yaitu dilakukan analisa data yang bertujuan untuk mempermudah data dipahami kemudian dibuat kesimpulan. Kesimpulan dari analisis data diperoleh dari sampel yang dibuat berdasarkan pengujian hipotesis (Ardiansyah, 2019). Pada hasil uji statistik One Way Anova, menunjukkan adanya perbedaan yang signifikan antara konsentrasi 20\%,40\%,60\% dan 80\% dengan kontrol positif dan kontrol negatif karena signifikansinya $<0,05$. Dari hasil pengamatan aktivitas antibakteri pada ekstrak Daun Afrika (Vernonia amygdalina Del.) terhadap pertumbuhan bakteri Escherichia coli dapat diketahui bahwa aktivitas antibakteri yang paling baik dihasilkan pada konsentrasi $80 \%$ dengan daya hambat sebesar 16,60 $\pm 0,17 \mathrm{~mm}$. Dari hasil tersebut dapat dilihat bahwa perbedaan konsentrasi menyebabkan zona hambat yang berbeda. Karena semakin tinggi konsentrasi, semakin tinggi pula kandungan zat aktif yang terkandung dalam ekstrak, sehingga memiliki aktivitas antibakteri lebih tinggi (Surjowardojo dkk, 2015). 
MEDFARM: Jurnal Farmasi dan Kesehatan, Vol.10, No.1, 2021, Hal. 28-34

e-ISSN : 2715-9957

p-ISSN: 2354-8487

\section{SIMPULAN}

Dari hasil penelitian yang telah dilakukan, dapat disimpulkan bahwa konsentrasi ekstrak etanol Daun Afrika (Vernonia amygdalina Del.) yang dapat menghambat pertumbuhan bakteri Escherichia coli menurut penelitian yang sudah dilakukan yaitu paling tertinggi adalah pada kosentrasi $80 \%$ dengan daya hambat sebesar 16,60 $\pm 0,17 \mathrm{~mm}$. Lebih besar dibandingkan dengan konsentrasi $20 \%, 40 \%$ dan $60 \%$.

\section{DAFTAR PUSTAKA}

Badan Pengawas Obat dan Makanan. 2005. Keputusan Kepala Badan Pengawas Obat dan Makanan Republik Indonesia Nomor HK. 00.05.1.52.0685 tahun 2005 tentang Ketentuan Pokok Pengawasan Pangan Fungsional. Jakarta: BPOM

Dedy Muzaki, Rekna Wahyuni. 2015. Pengaruh Penambahan Gingger Kering Zingiber officinale Terhadap Mutu dan Daya Terima Teh Herbal Daun Afrika Selatan Vernonia amygdalina Del. Jurnal Teknologi Pangan Vol. 6 Nomor 2

Ferry, Anwar. 2015. Perbandingan Efektivitas Daun Mengkudu dan Daun Binahong Terhadap Penurunan Kadar Glukosa Darah Mencit (Mus musculus). Skripsi FKIP Unpas Bandung.

Ijeh I.I. and Ejike C.E.C.C. 2010. Current Perspectives on The Medicinal Potentials of Vernonia amygdalina, Journal of Medicinal Plants Research, 5 (7), 10511061

Kusuma, S.A.F., 2010. PCR, Bandung

Madigan, M. 2005. Brock Biology of Microorganism. Englewood Cliff: Prentice Hall

Pratiwi, dkk. 2018. Uji Aktivitas Antibakteri Ekstrak Etanol Daun Afrika (Vernonia amygdalina Del.) Terhadap Bakteri Staphylococcus aureus. Universitas Cendrawasih. Jayapura.

Radji, Maksum. 2010. Buku Ajar Mikrobiologi Panduan Mahasiswa Farmasi dan Kedokteran. Jakarta: EGC.

Surjowardojo, dkk. 2015. Daya Hambat Dekok Kulit Apel Manalagi (Malus Sylvestrs Mill.) Terhadap Pertumbuhan Staphylococcus Aureus Dan Pseudomonas Sp. Penyebab Mastitis Pada Sapi Perah. Fak. Peternakan. Universitas Brawijaya 
MEDFARM: Jurnal Farmasi dan Kesehatan, Vol.10, No.1, 2021, Hal. 28-34

e-ISSN : 2715-9957

p-ISSN: 2354-8487

Suryati, N, dkk. 2017. Uji Efektivitas Antibakteri Ekstrak Aloe Vera Terhadap Pertumbuhan Escherichia coli Secara In Vitro. Fak.Kedokteran. Universitas Andalas Padang. Jurnal Kesehatan Andalas :6(3)

Sutton, S. 2011. Determination of Inoculum for Microbiological Testing. Summer Vol. 15 Number 3 